\title{
Influence of processing temperature on chemical composition of solar-dried blood meal and on performance of broiler chickens
}

\author{
A. Donkoh, D.M. Anang, C.C. Atuahene and M.A.S. Hagan \\ Department of Animal Science, \\ Kwame Nkrumah University of Science and Technology \\ Kumasi, Ghana
}

(Received 6 February 2002; accepted 2 August 2002)

\begin{abstract}
An experiment was conducted to ascertain the optimum temperature for cooking (pre-heating) raw blood before solar drying. Raw blood was subjected to three cooking temperatures $\left(50^{\circ}, 70^{\circ}\right.$ and $90^{\circ} \mathrm{C}$ ) for $30 \mathrm{~min}$ before solar drying at a temperature range from $45^{\circ}$ to $56^{\circ} \mathrm{C}$. In a feeding trial, four hundred and eighty 14-day-old broiler chickens were randomly allocated to four groups. The dietary treatments consisted of the control diet, which contained fish meal and soyabean meal as the main protcin sources, and three isoenergetic and isoprotein diets each of which contained $75 \mathrm{~g}$ of one of the three types of solar dried blood meals (SDBM) $\mathrm{kg}^{-1}$. Feed and water were provided ad libitum for a period of 6 weeks.

There was no significant effect of the cooking temperature on the chemical composition of the solar-dried blood meals. The dietary treatments did not have significant $(\mathrm{P}>0.05)$ impact on feed intake, body weight gain, feed conversion efficiency or carcass yields. There were no health-related problems nor mortality attributable to the addition of SDBM to the diet.
\end{abstract}

KEY WORDS: processing temperature, blood meal, chemical composition, broiler chickens, growth performance

\section{INTRODUCTION}

Fish meal is an important constituent of broiler chickens diets because of its high protein content and good amino acid profile. However, its use is constrained by its high cost with consequent high prices of eggs, poultry meat and products. There is, therefore, the need for continuous search for new dietary protein ingre- 
dients. The slaughter of animals for meat purposes generates considerable amount of blood (Ayangbile et al., 1993). Blood meal contains about $800 \mathrm{~g}$ protein $\mathrm{kg}^{-1}$ dry matter (DM), $90 \mathrm{~g}$ lysine $\mathrm{kg}^{-1} \mathrm{DM}$ and small amounts of ash and lipids. However, a notable feature of raw blood is its high moisture content. This makes it particularly sensitive to deterioration by endogenous enzymes and to microbial putrefaction. It must necessarily be processed before incorporation into animal diets.

Various industrial procedures have been employed in preparing blood meal. However, in some areas, where conventional protein feedstuffs such as fish meal are either scarce or expensive, blood from slaughterhouses is discharged into drains, streams and rivers, thus polluting the environment because facilities for drying may not be available. This points to the need for simple procedures for preparing blood meal to be used in poultry feeds. In the tropics, where there is abundance of sunlight, solar drying has been advocated as a simpler and cheaper method for drying than other industrial methods. Donkoh et al. (1999) described a solar-drying method in which the raw blood from the slaughterhouse was pre-heated in an open pan for $30 \mathrm{~min}$ at a temperature of $60^{\circ} \mathrm{C}$ to facilitate evaporation of water and coagulation. The coagulated blood, together with the small amount of the liquid fraction which remained, was transferred to a solar dryer for drying at $35^{\circ}-50^{\circ} \mathrm{C}$ to a moisture content of about $100 \mathrm{~g} \mathrm{~kg}^{-1} \mathrm{DM}$. However, evidence indicates that processing may, if not carried with careful control, reduce the nutritive value of the product. Overheating during the preparation of blood meal can seriously lower digestibility and the availability of specific amino acids, particularly lysine (Hamm and Searcy, 1976; Moughan and Donkoh, 1991; Crawshaw, 1994; NRC, 1994). Since blood is susceptible to damage from processing, an optimum temperature for cooking (pre-heating) raw blood efficiently without damaging the nutritive quality would be desirable for the solar-drying technique.

The objective of this study was to determine the optimum temperature for cooking raw blood before solar drying and further ascertain the growth performance of broiler chickens fed diets containing the variously processed meals.

\section{MATERIAL AND METHODS}

The blood used in the study was obtained from the Meat Science Unit of the Department of Animal Science, Kwame Nkrumah University of Science and Technology, Kumasi (Ghana). The raw material comprised mainly of blood obtained as a result of pig slaughterings but included small amount of that of cattle. The raw blood was divided into four portions and subjected to the following heating regimens: Treatment 1: raw clotted blood was placed in the solar dryer without pre-heating, Treatment 2: raw blood was heated in an open pan for $30 \mathrm{~min}$ at a temperature of $50^{\circ} \mathrm{C}$, 
Treatment 3: raw blood was heated for 30 min at a temperature of $70^{\circ} \mathrm{C}$, Treatment 4: raw blood was heated for $30 \mathrm{~min}$ at a temperature of $90^{\circ} \mathrm{C}$.

The coagulated blood from Treatments 2,3 and 4 were transferred to a solar dryer. The dryer consisted of a four-panel solar collector, which contained a blackpainted absorber. The collector was covered by a transparent, ultra-violet stabilised polythene sheet. Three axial flow fans of 40-watt output each are positioned under the collector, and one end of the tunnel was sealed. The fans, powered by a photovoltaic solar panel mounted above the collector, forced the hot air through the tunnel into a drying chamber. Access to the drying chamber was through a wooden gate at the top of the chamber. The wooden gate was covered with a fly-proof net, which allowed the dehydrating air to escape. Incoming air had to pass the fans at the end of the collector, although measures were taken to prevent dirt from entering the chamber. The aim of the process was to encourage the evaporation of moisture from the surface of the blood and the migration of moisture from inside the coagulated blood to its surface. Crucial factors in this process included ensuring a steady flow of warm air. The temperature, air speed and relative humidity were measured during the drying process using Almemo 2290-8 data logger (Table 1). The recording of data took place between 08.00 and $18.00 \mathrm{~h}$ GMT. The rate of dehydration was measured by weighing the blood at 2 -h intervals. The raw blood. which was not cooked before being placed in the solar dryer, deteriorated in condition (i.e. got rotten) and was therefore discarded.

TABLE !

Drying conditions recorded in the solar tunnel and outside between 08.00 and 18.00 GMT

\begin{tabular}{|c|c|c|c|c|}
\hline \multirow{2}{*}{ Parameters } & \multicolumn{2}{|c|}{ Solar tunnel } & \multicolumn{2}{|c|}{ Ambient } \\
\hline & minimum & maximum & minimum & maximum \\
\hline Temperature, ${ }^{\circ} \mathrm{C}$ & 45 & 56 & 26 & 31 \\
\hline Relative humidity, \% & 19 & 30 & 56 & 76 \\
\hline Air speed, $\mathrm{ms}^{-1}$ & 0.28 & 0.52 & 0.12 & 0.30 \\
\hline Dehydration rate, $\mathrm{gH}_{2} \mathrm{O} \mathrm{min}^{-1}$ & \multicolumn{2}{|l|}{12.8} & \multicolumn{2}{|c|}{8.6} \\
\hline
\end{tabular}

Proximate analyses (dry matter, crude protein, ether extract, ash and crude fibre) of the variously processed solar-dried blood meals (SDBM) were carried out using the standard procedures of the AOAC (1990) while water activity was measured using a Durotherm aw Wert-Messer meter. Available lysine contents of the SDBMs were determined by the Ousterhout and Wood (1970) modification of the method of Kakade and Liener (1969). The metabolizable energy (ME) contents of the different types of SDBM were estimated using the formula indicated by Pauzenga (1985):

$\mathrm{ME}(\mathrm{kcal} / \mathrm{kg})=(37 \mathrm{x} \%$ protein $)+(81.8 \times \%$ fat $)+(35.5 \times \%$ nitrogen-frec extractives). 
The chemical composition of the SDBMs is presented in Table 2.

Total surface viable microbial counts and isolation (Table 3) were determined on the fresh blood and each of the three types of SDBM by the method outlined by Bainbridge et al. (1996), while identification of microbes, which involved the examination of colonial characteristics, morphology, motility, staining and biochemical properties, was carried out using the guidelines of the International Commission on Microbiological Specifications for Food (1978).

TABLE 2

Dry matter content, $\mathrm{g} \mathrm{kg}^{-1}$ and chemical composition ${ }^{1}$ of the three types of processed blood meal (in $\mathrm{g} \mathrm{kg}^{-1} \mathrm{DM}$, except water activity and ME)

\begin{tabular}{lccc}
\hline \multirow{2}{*}{ Component } & \multicolumn{3}{c}{ Typc of blood mcal } \\
\cline { 2 - 4 } & SDBM1 & SDBM2 & SDBM3 \\
\hline Dry matter & 950.0 & 960.0 & 950.0 \\
Water activity, $\mathrm{a}_{\mathrm{w}}$ & 0.22 & 0.20 & 0.22 \\
Crude protein & 819.0 & 825.0 & 836.0 \\
Crude fibre & 30.0 & 36.0 & 31.0 \\
Ether extract & 13.2 & 13.7 & 14.7 \\
Ash & 42.0 & 40.0 & 41.0 \\
Nitrogen-free extractives & 45.8 & 45.3 & 34.0 \\
Available lysine & 72.8 & 73.5 & 73.0 \\
Metabolizable energy, MJ kg-1 & $13.8 !$ & 13.92 & 13.84 \\
\hline
\end{tabular}

'each value is the mean of triplicate determinations

TABLE 3

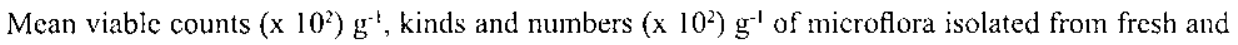
processed blood

\begin{tabular}{lcccc}
\hline ltem & Fresh sample & SDBMI & SDBM2 & SDBM3 \\
\hline Mean viable count & $20.9 \pm 0.60$ & $2.6 \pm 0.15$ & $2.4 \pm 0.18$ & $2.7 \pm 0.17$ \\
Species & & & & \\
Coliforms & $1.8 \pm 0.25$ & $0.4 \pm 0.09$ & $0.3 \pm 0.05$ & $0.5 \pm 0.07$ \\
Escherichia coli & $2.7 \pm 0.26$ & $0.1 \pm 0.01$ & $0.2 \pm 0.03$ & $0.1 \pm 0.02$ \\
Mucor spp. & $6.5 \pm 0.38$ & $0.7 \pm 0.10$ & $0.8 \pm 0.09$ & $0.8 \pm 0.10$ \\
Proteus spp. & $3.3 \pm 0.41$ & $0.5 \pm 0.11$ & $0.4 \pm 0.08$ & $0.6 \pm 0.10$ \\
Staphylococcus spp. & $3.6 \pm 0.32$ & $0.6 \pm 0.15$ & $0.8 \pm 0.19$ & $0.9 \pm 0.18$ \\
\hline
\end{tabular}

'each value is the mean of triplicate determinations

Four experimental diets (Table 4) were formulated: a control diet which contained no SDBM and diets 1,2 and 3 which contained $75 \mathrm{~g} \mathrm{SDBM} 1$ (preheated at 
$50^{\circ} \mathrm{C}$ ), SDBM 2 (preheated at $70^{\circ} \mathrm{C}$ ) and SDBM 3 (preheated at $90^{\circ} \mathrm{C}$ ) per kg diet, respectively. The diets were formulated to be isoprotein and isoenergetic.

TABLE 4

Composition of experimental broiler diets

\begin{tabular}{lrrrr}
\hline & \multicolumn{4}{c}{ Experimental diets } \\
\cline { 2 - 5 } & Control & \multicolumn{1}{c}{$\mathrm{I}$} & 2 & 3 \\
\hline Ingredients. g kg-1 & & & & \\
maize & 580 & 580 & 580 & 580 \\
solar-dried blood meal & 0 & 75 & 75 & 75 \\
fish meal & 190 & 100 & 100 & 100 \\
soyabean mcal & 60 & 35 & 35 & 35 \\
wheat bran & 140 & 180 & 180 & 180 \\
oyster shell, ground & 10 & 10 & 10 & 10 \\
dicalcium phosphate & 10 & 10 & 10 & 10 \\
vitamin/mineral premix & 5 & 5 & 5 & 5 \\
NaCl & 5 & 5 & 5 & 5 \\
& & & & \\
Chemical analysis, $\mathrm{g} \mathrm{kg}^{-1} \mathrm{DM}$ & & & & \\
crude protein & 223.1 & 221.3 & 221.8 & 222.1 \\
crude fibre & 34.4 & 38.4 & 38.8 & 38.5 \\
crude fat & 36.2 & 33.7 & 33.8 & 33.8 \\
lysine & 11.8 & 13.6 & 13.6 & 13.6 \\
methionine & 5.1 & 4.4 & 4.4 & 4.4 \\
isoleucine & 8.9 & 7.3 & 7.3 & 7.3 \\
ME, MJ kg ${ }^{-1 \mathrm{~b}}$ & 11.50 & 11.55 & 11.56 & 11.55 \\
\hline
\end{tabular}

"vitamin-mineral premix supplied ( $\mathrm{kg}^{-1}$ diet): vit. A, 7500 IU; vit. $\mathrm{D}_{3}, 2200 \mathrm{IU}$; vit. E, $9.5 \mathrm{IU}$; (mg): vit. K, 1.7; riboflavin, 2.5; cobalamin, 0.05; pantothenic acid, 6; niacin, 20; choline, 240; folic acid, $0.5 ; \mathrm{Mg}, 2.3 ; \mathrm{Fe}, 45 ; \mathrm{Cu}, 5.5 ; \mathrm{Mn}, 55 ; \mathrm{Zn}, 50 ; \mathrm{I}, 0.8 ; \mathrm{Co}, 0.2 \mathrm{mg}$

${ }^{b}$ calculated according to National Research Council data (1994)

Four hundred and eighty unsexed 14-day-old commercial broiler chickens (Afabro strain) were individually weighed. Three replicates were allotted randomly to the four dietary treatments. Forty birds were placed in deep litter pens each measuring $9.6 \mathrm{~m}^{2}$. The study was conducted for 42 days. Birds had free access to feed and water throughout the experimental period. Chickens were vaccinated against Gumboro and Newcastle diseases. They were also protectively medicated for Coccidiosis at 3 days of age and again during the third week using sulphadimidine sodium $33 \%$ via the drinking water.

The parameters studied included: feed intake, body weight gain and feed conversion efficiency (feed:gain ratio). Records of mortality were also kept. At 56 days of age, all birds were weighed and four broilers from each of the 12 replicates were selected at random, starved of feed for $18 \mathrm{~h}$, killed by cutting the jugu- 
lar vein, exsanguinated, defeathered and eviscerated. Carcass yield was calculated from eviscerated weight and liveweight.

Statistical analysis was accomplished by the one-way analysis of variance (Steel et al., 1997).

\section{RESULTS AND DISCUSSION}

The data on the drying conditions recorded between 08.00 and $18.00 \mathrm{GMT}$ are presented in Table 1 . The maximum temperature attained in the solar drying chamber was $56^{\circ} \mathrm{C}$, which was $25^{\circ} \mathrm{C}$ higher than the ambient temperature. A high and constant wind speed increased the rate of drying. Using the solar tunnel, the times for the drying of the blood cooked at $50^{\circ}, 70^{\circ}$ and $90^{\circ} \mathrm{C}$ were 48,36 and $24 \mathrm{~h}$, respectively, compared to 84,72 and $60 \mathrm{~h}$ for the traditional open air method. The longer time taken by the blood sample cooked at $50^{\circ} \mathrm{C}$ to dry might be attributed to the high moisture content after cooking compared with that cooked at $90^{\circ} \mathrm{C}$. As indicated earlier, the uncooked (raw) blood got rotten when it was placed in the solar dryer and was therefore discarded. The spoilage of the uncooked blood sample might be attributed to its high moisture content and temperature, which made it susceptible to rapid deterioration by endogenous enzymes and to microbial putrefaction. Thus, raw blood must be preheated or cooked before solar drying to facilitate evaporation and coagulation and therefore enhance the keeping quality during solar drying. However, in cooking, care should be taken to avoid prolonged heating since this can result in considerable damage to the protein with the loss of digestibility and protein quality (Miller and De-Boer, 1988).

The results of the chemical analysis (Table 2) of the three types of processed blood meals show the products to be good sources of bigh quality nutrients. The fact that the SDBM contained high amounts of total protein $\left(819-830 \mathrm{~g} \mathrm{~kg}^{-1}\right)$ and available lysine (72.8-73.5 $\mathrm{g} \mathrm{kg}^{-1}$ ) indicates that the processing conditions used did not adversely affect the nutritional quality of the resultant products. Crude protein and available lysine content in meals are similar to values reported by Donkoh et al. (1999) for SDBM preheated at $60^{\circ} \mathrm{C}$ before solar drying.

A moisture content of $5 \%$ and water activity of $0.22 \mathrm{a}_{\mathrm{w}}$ will inhibit the growth and development of microorganisms, while yeast or mould cannot grow at water activity level of below $0.62 \mathrm{a}_{\mathrm{w}}$. The water activity level of $0.22 \mathrm{a}_{\mathrm{w}}$ obtained in the meals falls below the guidelines of the Food and Agriculture Organization (1990) for dried products $\left(0.5 \mathrm{a}_{\mathrm{w}}\right.$ to $\left.0.75 \mathrm{a}_{\mathrm{w}}\right)$. Consequently, the SDBMs will have long shelf life.

There was no impact of processing condition on the mean total viable microflora count of the processed blood meals. In all it was lower than in the fresh blood sample (Table 3). Microflora isolated from the fresh blood samples included 
Staphylococcus spp., coliforms, Escherichia coli, Proteus spp. and Mucor spp. The samples were, however, free from pathogenic bacteria such as faecal coliform bacteria and Salmonella. Similarly, Staphylococcus spp., coliforms, Escherichia coli, Proteus spp. and Mucor spp. were recovered from the solar-dried blood meals, though at relatively lower numbers. Tests for the microbiological counts of the various blood meals indicate that dehydration alone may not be sufficient to eliminate microorganisms, demonstrating the need for strict hygiene before and after the drying process.

The general performance of the experimental chickens is shown in Table 5. Average feed consumption per bird for the 6-week period ranged from 3.39 to $3.51 \mathrm{~kg}$. Fecd intake by broiler chickens was not significantly $(P>0.05)$ influenced by the inclusion of the various SDBM in diets.

TABLE 5

Effect of processed blood meal on the performance of broiler chickens over the period from 14 to 56 days of age

\begin{tabular}{lccccc}
\hline \multirow{2}{*}{ Indices } & \multicolumn{5}{c}{ Dictary treatments } \\
\cline { 2 - 5 } & Control & 1 & 2 & 3 & SEM \\
\hline Feed intake, $\mathrm{kg}$ & 3.45 & 3.39 & 3.40 & 3.51 & 0.09 \\
Protein intake, $\mathrm{kg}$ & 0.77 & 0.75 & 0.75 & 0.78 & 0.013 \\
Initial body weight, kg & 0.226 & 0.231 & 0.228 & 0.220 & - \\
Body weight gain, kg & 1.74 & 1.62 & 1.69 & 1.73 & 0.03 \\
& & & & & \\
Feed conversion ratio, & & & & & \\
$\quad$ kg feed/kg body weight gain & 1.98 & 2.09 & 2.01 & 2.03 & 0.002 \\
Mortality, \% & 0.83 & 0.83 & 1.67 & 1.67 & 0.33 \\
Carcass yield, \% LBW & 70.5 & 70.3 & 70.3 & 71.1 & 0.004 \\
\hline
\end{tabular}

SEM - standard error of mean

$\mathrm{n}=120$ birds for each dietary treatment, with 3 replicates per treatment

LBW - live body weight

Similarly, there were no substantial differences in mean body weight gains between birds fed the SDBM-free (control) diet and those which contained the different types of SDBM. The efficiency with which feed was converted to weight gain (feed:gain ratio) was also unaffected by dietary treatments.

The carcass yields of broiler chickens fed diets with or without SDBM were similar, indicating the inclusion of the SDBM preheated to various temperatures before solar drying, exerted no significant impact on this parameter.

A total of seven mortality cases were recorded during the experimental period (Table 5). Post-mortem autopsies indicated no specific causes for deaths attributable to inclusion of the SDBM. 
It seems that raw blood may be cooked between the temperatures of $50^{\circ}$ and $90^{\circ} \mathrm{C}$ before solar drying to facilitate evaporation of water and coagulation without adverse effect on the chemical composition and nutritional value of the SDBM. The lowest cooking temperature effectively prevented deterioration of the blood meal as the higher cooking temperatures and thus its use might be more economical. Processed blood meals may be included in broiler diets at a level of $75 \mathrm{~g}$ $\mathrm{kg}^{-1}$ in place of fish meal and other protein sources without detrimental effects on growth performance.

\section{REFERENCES}

AOAC, 1990. Official Methods of Analysis, Association of Official Analytical Chemists. 15th Edition. Arlington, VA

Ayangbile O.A., Tallan S.K., Surtan M.S., 1993. Processing of slaughterhouse blood and poultry litter and the effects on nutrient digestibility by steers. Anim. Feed Sci. Tech. 40, 153-164

Bainbridge Z., Tomlins K., Wellings K., Westby A., 1996. Methods for Assessing Quality Characteristics of Non-Grains Starch Staples. Part 3. Laboratory Methods. Natural Resources Institute, Chatham (UK)

Crawshaw R., 1994. Blood Meal: a Review of its Nutritional Qualities for Pigs, Poultry and Ruminant Animals. National Renderers Association Technical Review. UK, 594, p.7

Donkoh A., Atuahene C.C., Anang D.M., Ofori S.K., 1999. Chemical composition of solar-dried blood meal and its effect on performance of broiler chickens. Anim. Feed Sci. Tech. 81, 299-307

Food and Agriculture Organization, 1990. Manual on Simple Methods of Meat Preservation. Animal Production and Health, Paper No. 79

Hamm D., Searcy G.K., 1976. Some factors which affect the availability of lysine in blood meals. Poultry Sci. 55, 582-587

International Commission on Microbiological Specifications for Food, 1978. Microorganisms in Foods 1. Their Significance and Methods of Enumeration. 2nd Edition. University of Toronto Press, Toronto (Canada)

Kakade M.L., Liener I.E., 1969. A simplified procedure for the determination of available lysine in protein and protein foodstuffs. Anal. Biochem. 27, 273-280

Miller E.L., De-Boer F, 1988. By-products of animal origin. Livest. Prod. Sci. 19, 159-196

Moughan P.J., Donkoh A., 1991. Amino acid digestibility in non-ruminants - a review. In: D.J. Farrell (Editor). Recent Advances in Animal Nutrition in Australia. University of New England, Armidale (Australia), pp. 172-184

National Research Council, 1994. Nutrient Requirements of Domestic Animals. Nutrient Requirements of Poultry. 9 th revised Edition. National Academy Press, Washington, DC

Ousterhout L.E., Wood E.M., 1970. Available lysine in fish meals: chemical (TNBS) method compared with chick assay. Poultry Sci. 49, 1423 (Abstr.)

Pauzenga U., 1985. Feeding parent stock. Zootech. Int. December, pp. 22-24

Stecl R.G.D., Torric J.H., Dickey, D.A., 1997. Principles and Procedures of Statistics. A Biometrical Approach. 3rd Edition. McGraw-Hill, New York 


\section{STRESZCZENIE}

Wplyw temperatury na skład chemiczny suszonej na slońcu mączki z krwi i wyniki produkcyjne kurcząt brojlerów

Celem doświadczenia było określenie optymalnej temperatury podczas wstępnego ogrzewania surowej krwi przed jej suszeniem na słońcu.

Surową krew ogrzewano w temperaturze $50^{\circ}, 70^{\circ}$ lub $90^{\circ} \mathrm{C}$ przez 30 min przed suszeniem jej na słoń$\mathrm{cu}$, w temperaturze wahającej się od $45^{\circ}$ do $56^{\circ} \mathrm{C}$. W 6-cio tygodniowym doświadczeniu żywieniowym, 408 14-to dniowych kurcząt brojlerów podzielono losowo do 4 grup i żywiono następującymi dietami: kontrolną, w której głównym źródłem białka była mączka rybna i śruta sojowa oraz 3 izoenergetycznymi izobiałkowymi dietami, zawierającymi po $75 \mathrm{~g}$ jednej z trzech rodzajów mączki z krwi (SDBM) $\mathrm{kg}^{-1}$. Pasze i woda podawane były do woli.

Nie stwierdzono istotnego wpływu temperatury ogrzewania na skład chemiczny suszonej na słońcu mączki z krwi. Podobnie nie stwierdzono istotnych różnic $(\mathrm{P}>0,05)$ w pobraniu paszy, przyrostach, wykorzystaniu paszy oraz wydajności rzeźnej, a także w stanie zdrowia i upadkach kurcząt pomiędzy grupami. 